\title{
Angelaki
}

\section{Intensive Genre and the Demise of Gender}

\section{Rosi Braidotti}

To cite this article: Rosi Braidotti (2008) Intensive Genre and the Demise of Gender, Angelaki, $13: 2,45-57$

To link to this article: http://dx.doi.org/10.1080/09697250802432112

$$
\text { 曲 Published online: } 16 \text { Oct } 2008 .
$$

Submit your article to this journal

Џll Article views: 158

Q View related articles $\asymp$ 
If we had a keen vision and feeling of all ordinary human life, it would be like hearing the grass grow and the squirrel's heart beat, and we should die of that roar which lies on the other side of silence. As it is, the quickest of us walk about well wadded with stupidity.

George Eliot, Middlemarch 226

We leave a great blank here, which must be taken to indicate that the space is filled to repletion.

Virginia Woolf qtd in Lee, Virginia Woolf 528

You have the individuality of a day, a season, a year, a life [...], a climate, a wind, a fog, a swarm, a pack [...] A cloud of locusts carried in by the wind at 5 in the evening; a vampire who goes out at night, a werewolf at full moon [...] It is the entire assemblage in its individuated aggregate that is a haecceity [...] It is the wolf itself, and the horse, and the child that cease to be subjects to become events, in assemblages that are inseparable from an hour, a season, an atmosphere, an air, a life.

Deleuze and Guattari, Mille Plateaux 262; emphasis in original

$\mathrm{n}$ this essay I want to argue that Virginia

Woolf's extensive corpus constitutes a singular example of an intensive genre that cuts transversally across a number of established literary forms to constitute a qualitative mode of its own. I will connect this intensive genre to the process of nomadic becoming, with special emphasis on the concepts of creativity and desire. I will argue that Woolf's work exemplifies not only the becoming woman/animal/world in the minoritarian mode theorized by Gilles Deleuze and Félix Guattari but also the process that is immanent to all others and hence more powerful (in the sense of potentia $^{1}$ ), namely the becoming-imperceptible.

\section{rosi braidotti}

\section{INTENSIVE GENRE AND THE DEMISE OF GENDER}

In this respect, Woolf”s "stream-of-consciousness" style expresses with uncanny precision the seriality as well as the radical immanence and the structural contingency of the patterns of repetition by which qualitative processes of transformation can be actualized. Thus Woolf invents a genre of her own - the intensive genre of becoming.

\section{nomadic becomings and woolf's intensive genre}

Creativity is a nomadic process in that it entails the active displacement of dominant formations of identity, memory and identification. Becoming nomadic as a variation on the theme of becomingminoritarian is neither the swinging of the pendulum of dialectical opposition, nor is it the 
unfolding of an essence in a teleologically ordained process supervised by a transcendent consciousness. Nomadic becomings are rather the process of affirmation of the unalterably positive structure of difference, unhinged from the binary system that traditionally opposed it to Sameness. Difference as positivity entails a multiple process of transformation, a play of complexity that expresses the principle of not-One. Accordingly, the thinking subject is not the expression of in-depth interiority, nor is it the enactment of transcendental models of reflexive consciousness. It is a collective assemblage, a relay-point for a web of complex relations that displace the centrality of ego-indexed notions of identity. Deleuze argues that, considering the de-territorializing force of processes of becoming, they gather force from some energetic core, or vibrating hub of activity which is the creative pole of power as potentia. This is opposed to the restrictive pole of institutionalized power as potestas, which can only replicate and perpetuate it. Only potential or joyful affirmation had the power to generate qualitative shifts in the processes of becoming, hence the axiom that there is becoming other than minoritarian/ nomadic/woman/animal/other. According to Gatens and Lloyd this nomadic becoming is an ethology, that is to say, a process of expression, composition, selection, and incorporation of forces aimed at positive transformation of the subject. As such it is also crucial to the project of a creative redefinition of philosophical reason and of its relation to conceptual creativity, imagination and affectivity.

Becoming has to do with emptying out the self, opening it out to possible encounters with the "outside." Virginia Woolf's intensive genre is exemplary here, in that the artist's "eye" captures the outside world by making itself receptive to the totality of perception. What gets activated is a seemingly absent-minded floating attention or a fluid sensibility that is porous to the outside and which our culture has coded as "feminine." This sensibility is central to the creative process. It combines the accuracy of the cartographer with the hyper-sensitivity of the sensualist in apprehending the precise quality of an assemblage of elements, like the shade of the light at dusk or the curve of the wind just before the rain falls. In those moments of floating awareness when rational control releases its hold, "Life" rushes on towards the sensorial/perceptive apparatus with exceptional vigour and higher degrees of definition. This onrush of data, information and affectivity is the relational bond that simultaneously propels the self out of the black hole of its atomized isolation and disperses it into a myriad of bits and pieces of data imprinting or impressions. Conceptualized by Deleuze as the folding in and out of perception, it also confirms the singularity of that particular entity which both receives and recomposes itself around the onrush of data and affects.

One needs to be able to sustain the impact with the onrushing affectivity to "hold" it, without being completely overwhelmed by it. But "holding" it or capturing it does not occur on the paranoid or rapacious model of a dominant, dialectically driven consciousness. It rather takes the form of a sustainable model of an affective, de-personalized, highly receptive subject which quite simply is not one, not there, not that. As Virginia Woolf put it: "I am rooted, but I flow" (The Waves 69). The singularity of this nomadic, floating subjectivity rests on the spatio-temporal co-ordinates that make it possible for him/her to coincide with nothing more than the degrees, levels, expansion and extension of the head-on rush of the "outside" folding inwards. What is mobilized is one's capacity to feel, sense, process and sustain the impact with the complex materiality of the outside.

The processes and flows of becoming, and the heightened states of perception and receptivity which they both assume and engender, defy the canonical genre classifications and install a sort of parallelism between the arts, sciences and conceptual thinking. The point of convergence is the quest for creativity, in the form of experimenting with the immersion of one's sensibility in the field of forces - formatted as by music, colour, sound, light, speed, temperature and intensity. In Qu'est-ce que la philosophie? Deleuze and Guattari argue, for instance, that writers speak the unsayable; painters make visible forces that previously were not, much as composers make us hear sounds that were unheard of. 
Similarly, philosophers can make thinkable concepts that did not exist before. Artistic genres are variables co-existing along a continuum. It comes down to a question of style, but style here is no mere rhetorical device, it is rather a navigational tool. It negotiates our path across sets of material co-ordinates that, assembled and composed in a sustainable and enduring manner, allow for the qualitative transformation of the affects and the forces involved. They thus trigger the process of becoming.

The imagination plays a crucial role in enabling the whole process of becomingminoritarian and hence of conceptual creativity and ethical empowerment. It is connected to memory: the affective force of remembrance is the propelling of becoming-intensive. When you remember in the intensive- or minority-mode you open up spaces of movement and of de-territorialization that actualize virtual possibilities which had been frozen in the image of the past. Opening up these virtual spaces is a creative effort. When you remember to become what you are - a subject-in-becoming - you actually reinvent yourself on the basis of what you hope you could become with a little help from your friends.

It is crucial, in fact, to see to what extent processes of becoming are collective, intersubjective and not individual or isolated: it is always a matter of blocks of becoming. "Others" are the integral element of one's successive becomings. A Deleuzian approach favours the destitution of the liberal notion of the sovereign subject altogether and consequently overcomes the dualism Self/ Other, Sameness/Difference which is intrinsic to that vision of the subject. Subjects are collective assemblages, that is to say they are dynamic, but framed: fields of forces that aim at duration and affirmative self-realization. In order to fulfil them, they need to be drawn together along a line of composition. This is rather like pitching a musical tone.

Remembering in this nomadic mode is a key element of this process. Woolf's work reflects the dual structure of time: the linear one - Chronos and the undifferentiated one - Aion. Being and Becoming confront each other in an unsteady balance. Aion is the "pure empty form of time,"

\section{braidotti}

free of content, which is shot through with vibrations of becoming. If this be chaos, it is not chaotic, but generative (Ansell Pearson). It produces assemblages that organize space and time around them. The "haecceity" or individuated aggregate is the specific and highly contingent actualization of a field of forces stable enough and consolidated by their structural affinity, so as to be able to constitute a plane of immanence.

Remembering in the nomadic mode is the active reinvention of a self that is joyfully discontinuous, as opposed to being mournfully consistent, as programmed by phallogocentric culture. It destabilizes the sanctity of the past and the authority of experience. The tense that best expresses the power of the imagination is the future perfect: I will have been free. Quoting Virginia Woolf, Deleuze also says: "This will be childhood, but it must not be my childhood" (Deleuze and Guattari, A Thousand Plateaus 294). Shifting away from the reassuring platitudes of the past to the openings hinted at by the future perfect. This is the tense of a virtual sense of potential. Memories need the imagination to empower the actualization of virtual possibilities in the subject. They allow the subject to differ from oneself as much as possible while remaining faithful to oneself, or in other words: enduring.

The "plane of immanence" composes and sustains the actualization of processes of becoming as relational, external and collective. This process of composition and assemblage of forces is what desire is all about, as an ontological layer of affinity and sympathy between different enfleshed subjects.

This intensive approach to processes of becoming does not pursue a Hegelian project of recognition of consciousness and hence does not posit desire as lack or rationality as implicitly linked to the violent struggle for autonomy (Benjamin). Desire as plenitude rather challenges the matrix of having and lacking access to recognition by Self and Other as transcendent categories. Becoming is molecular, in that it requires singular overthrowing of the internalized simulacra of the self, consolidated by habits and flat repetitions. The dynamic vision of the subject as assemblage is central to a vitalist, yet 
anti-essentialist, theory of desire, which also prompts a new practice of sustainable ethics.

Desire is the propelling and compelling force that is driven by self-affirmation or the transformation of negative into positive passions. This is a desire not to preserve but to change: it is a deep yearning for transformation or a process of affirmation. Empathy and compassion are key features of this nomadic yearning for in-depth transformation. The space of becoming is a space of affinity and correlation of elements, among compatible and mutually attractive forces and the constitutive elements of the process. Proximity, attraction or intellectual sympathy is both a topological and qualitative notion: it is a question of ethical temperature. It is an affective framing for the becoming of subjects as sensible or intelligent matter. The affectivity of the imagination is the motor for these encounters and of the conceptual creativity they trigger off. It is a transformative force that propels multiple, heterogeneous "becomings" of the subject.

The sheer genius of Virginia Woolf rests in her ability to present her life as a gesture of passing through. In The Waves, for instance, Woolf captures the concrete multiplicity - as well as the shimmering intensity - of becoming. She is the writer of multiple and intransitive becomings, in-between ages, sexes, elements, and characters. Woolf's texts enact a flow of positions, a crossing of boundaries, and an overflowing into a plenitude of affects where life is asserted to its highest degree. She is an intensive multiplier of affects. Woolf also provides Deleuze with a model for the "plane of immanence," where different elements can encounter one another, producing those assemblages of forces, without which there is no becoming. She expresses with stark intensity the pain involved in trying to synchronize the heterogeneity of life as zoe, as positive vitality.

Although Deleuze recognizes the extraordinary position of Woolf as a conveyor or relay point for this passionate process of becoming in both Dialogues and $A$ Thousand Plateaus he is very careful to disengage Woolf's work from her being-a-woman, and even more from the "écriture féminine" style made popular by sexual difference feminism since the 1980s. Woolf's language expresses the free indirect speech that is central to the nomadic vision of the subject as heterogeneous assemblage. Yet something in what feminists of sexual difference call the "feminine libidinal economy" of excess without selfdestruction and desire as plenitude without lack is central to the whole Deleuzian project of becoming (Colebrook). This is why he positions the "becoming-woman" so prominently as a necessary moment of transition in his scheme of things, not only in his philosophy of the subject but also in the related theories of aesthetics and art. Nonetheless, as I have argued at length elsewhere (Braidotti 1991, 2002, 2006), Deleuze cannot resolve his ambivalence towards it.

Woolf's intensive genre and her flair for affirming positive passions provide not only a significant illustration of the functions of writing and desire but also for the project of an ethics of sustainability. The intensive text is an experimental site, a laboratory for the new in the sense of the actualizations of experiments in becoming. The literary text as an experiment in sustainable models of change is a laboratory grounded in accurate knowledge and subjected to the same rigorous rules of verification as science or philosophy. This fundamental parallelism cuts across different areas, disciplines and textual genres. Life, science and art are equally enlisted to the project of experimenting with transformations. The author, writer or agent is a complex multiplicity, a factor of empowerment of potentia, that is to say a multiplier of virtual possibilities, through the rigorous application of the rules of composition of assemblages. Life as $z o e$ is approached as a splendid complexity cosmic, or rather: "chaosmic" (Guattari, Chaosmosis) and vitalist in essence.

\section{free indirect speech or: writing with an accent}

Throughout Woolf's corpus of free indirect speech (her letters and diaries as well as in her fictional works) the figure of Vita SackvilleWest - her friend, lover and real-life model for Orlando - looms large. What is particularly striking is the highly defined field of perception that Woolf enacts and, in some ways, organizes. From their very first encounter in 1923, which 
was dutifully recorded in Woolf's diaries, through to the end of her life, Vita stands for a life force of mythical proportions. Clearly magnified through the lens of erotic desire, but stretching beyond the whimsical tricks of Eros, that cruel god, Vita endures in a field of her own which is one of perpetual becomings. Spatio-temporal co-ordinates gather around Vita, carried by her statuesque legs, the arch of her shoulders, the specific hue of her complexion: she organizes Virginia's cosmos around her. There's a specific quality of light around her, which is recorded and repeated in the diaries with mathematical precision. It has to do with the porpoise radiance and the lustre of pink and of pearls. There's an acceleration of life about Vita due to the speed of desire, but also to the more bearable lightness of becoming. The space gets filled with warmth, with that shimmering intensity which we also find in Woolf's novels. There's a heightening of sensorial perception, the flowing of deep-seated affinity, of immense compassion, to the very end:

Vita was here: and when she went, I began to feel the quality of the evening - how it was spring coming; a silver light; mixing with the early lamps; the cabs all rushing through the streets; I had a tremendous sense of life beginning; mixed with that emotion, which is the essence of my feeling, but escapes description [...] I felt the spring beginning and Vita's life so full and flush; and all the doors opening; and this is I believe the moth shaking its wings in me. (Woolf, Diary of Virginia Woolf, 16 February 1930, 287)

Virginia will remember these affects, and be able to retrieve their spatio-temporal co-ordinates throughout her life, even when the actual relationship with Vita has lost its brilliance. These spatio-temporal, geographical, historical and meteorological features are Vita - as a vector for $z o e$ - and constitute the plane of immanence where she and Virginia activate a process of becoming which goes beyond their psychological, amorous and sexual relationship. Something much more elemental, more raw, is at stake: desire draws its own affective landscapes.

The polymorphous vitalism of the VitaVirginia encounter enacts a block of becoming

\section{braidotti}

and the conditions for what we commonly would call desire. What I want to stress is the impersonal, or rather apersonal, nature of the interaction that is enacted in this encounter, however, and which makes it sustainable. This means that authors, characters, texts, friends and lovers are blocks of becoming actualizing the virtuality that is activated by their relation or interconnection. The space between us is active with intensity, it is fertile, generative. The affects, concepts and perceptions mobilized by art, science or literature are multiple, infinitesimal and located in a myriad of possible combinations which form that which mobilizes yet unactualized real-life potentials.

There is a sort of geometry, geology and meteorology of forces that gather round the actors - V \& V - but do not fully coincide with them. The reader can map out these forces, in an exercise that is an ethology of affects, or cartography of their effects. First and foremost among these effects, the sheer pleasure, the joy, even the jouissance, which is but a sort of acceleration, a becoming-intense of existence: "life so full \& flush," as Woolf admirably puts it. Secondly, and in some ways more importantly, it produces writing, as indicated by the reference to "the moth shaking its wings," which indicates the activation of Woolf's highly sensitive inner sensors. Becoming woman, animal and writing machine proceed at equal speed, framing a space of perfect stillness.

The best way to measure the intensity mobilized in this encounter and to assess the scale of its magnitude - and hence of the possible becomings it activates - is by turning to the literature itself: the letters and diaries as well as the fictional work. All of Virginia Woolf's relationships mixed work and play, life and writing, starting with Leonard himself. Vita with her looks, intensity and unconventional manners provided more fuel and of a higher quality than most. This is not to say that the affects and the passions are functional to the production of written work. Desire is a non-profit mechanism and its contribution to meaningful production is simply the form it takes to express itself: desire is always the desire to express and to make things happen. As Elspeth Probyn puts it: "desire here is no metaphor; it is a method of 


\section{intensive genre}

doing things, of getting places. Desire here is the mode of connection and communication between things, inevitably giving way to the literalness of things" (40). The immanent and intensive approach makes for an absence of metaphoricity and a renewed emphasis on concrete, literal actualizations.

Desire is, nonetheless, a surplus value that does ensue from the expression of affectivity and its successful encounter with other forces. It is a gift in some ways, but one that is disengaged from the political economy of exchanges regulated by lack and negativity. Virginia and Vita simply cannot help but write to, of and through each other: it is a case of addiction. Addiction to what? An addiction to "Life," a seduction into "Life," to the adrenalin charge, the intensification of existence, the rush of energy that occurs in the spatio-temporal zone of their encounter. The space between us is creative and generative, it frames a network of becoming, a spider's web of potentials. Together, we become other than what we were before we came close. Sexuality is not the "cause" or the driving force of this (these two women were only accidental lovers) but a mere consequence of some more fundamental shift of perspective that they operate for each other: potentia is activated (Grosz).

Let us look at the specific genre that is their correspondence. This is neither a biography nor a love letter; it is the unfolding, with meticulous regularity, of the virtual layers of potentia contained in the encounter between $V$ \& V. The actualization of multiple and virtual realities, possibilities such as they are perceived, recognized and amplified by that writer of genius that was Woolf. In her study of Woolf's correspondence, Kate Stimpson argues that the epistolary genre is very specific and can best be defined as an in-between space, bringing together the public and the private. As such, the letters possess a fluid quality that allows the readers to catch a glimpse of the fleeting state of the writer's mind. They transcribe free indirect speech with increased intensity. Moreover, the letters are interactive exchanges that construct an intersubjective space with her (privileged) interlocutor. The space of the letters is an in-between, a third party that does not fully coincide with either Virginia or Vita, but rather frames the space of their relationship. Read with Deleuze, it is a space of becoming. Read with Irigaray, it is a space of mediation of the love between them. Read with Glissant, it is a poetics of relation. As a mediating factor, it organizes space and time, thus allowing each partner to take care of the relationship as a space of transition. Virginia and Vita "write" one another into their life and they also produce a relationship as a space of transition. They draw a space of flow and becoming, a spider's web and rhizome, through a set of epistolary relations which are enacted in a communal, albeit volatile, communicative space. Today's equivalent would be e-mail exchanges.

Hermione Lee argues that in the relationship between V \& V "more was asked (on both sides) than could be given" (485) and that in their intense interchange they made each other up imaginatively. They cast each other in dramatic roles which fed their respective writing, whereby:

Virginia was the will of the wisp, the invalid, the frail virgin, the "ragamuffin" or "scallywag," the puritan [...] Vita was the rich, supple, luxurious, high-coloured, glowing, dusky, fruity, fiery, winy, passionate, striding, adventuring traveller, also dumb, dense, a "donkey." Virginia was the one with the head, Vita was the one with the legs. (485)

These imaginary constructions were their route to intimacy. This is no metaphor, but rather a vital form of literalness: conceptual personae activated and intensified. The intense and deep affectivity that is expressed in these letters opens a space of freedom that allows simultaneously for experiments with different writing techniques and for experimenting with residual spirituality and complex emotions. These letters, as Stimpson argues,

occupy a psychological and rhetorical middle space between what she wrote for herself and what she produced for a general audience. They are a brilliant, glittering encyclopaedia of the partially-said [...] the materials or a full autobiography of consciousness, mediation between life and work [...] They concern social worlds that she needed and wanted. They form an autobiography of the self with others, a citizen/denizen of relationships. (130) 
It is the link, the affinity, the bond of potentia and recognition between each of them as a complex multiplicity which results in setting the frame for the affirmation of the joyful potency of desire.

This high degree of intensity is all the more remarkable if you consider that, in real-life - the actual V \& V were far from the life forces that they happened to become together. Virginia could hardly sustain, in her frail body and even more vulnerable psychic balance, the intensity of the forces that she registered, evoked and recorded: she lived on the crack. As for Vita, Virginia put her finger on it with the disarming cruelty of her superior intelligence: "The thing I call central transparency sometimes fails you there too." And again: "There's something that doesn't vibrate in you; it may be purposely - you don't let it: but I see it with other people as well as with me: something reserved, muted..." (Nicolson and Trautman, Letters of Virginia Woolf III: 302, 10 November 1926).

That she hit the mark is testified by Vita's comments in her correspondence to her husband Harold Nicholson:

Damn the woman! She has put her finger on it. There is something that $[\ldots]$ doesn't come alive ... it makes everything I do (i.e.: write) a little unreal; it gives the effect of having been drawn from the outside. It is the thing which spoils me as a writer; destroys me as a poet [...] It is what spoils my human relationships too... (Nicolson, Vita and Harold, Letter of Vita to Harold, 20 November, 173)

But this fundamental opacity of Vita's soul is compensated and sustained by a feminine magnificence about her:

Vita very free \& easy, always giving me great pleasure to watch $\&$ recalling some image of a ship breasting a sea, nobly, magnificently, with all sails spread \& the gold sunlight on them. (Diary of Virginia Woolf, 4 July 1927, 146)

A Deleuzian feminist reader could draw a cartography of the affective forces that frame the encounters between $\mathrm{V} \& \mathrm{~V}$, such as they are reported in the diaries and the letters (literature and work of remembrance) as well as in the

\section{braidotti}

fiction (literature and work of the imagination). Again, I want to stress the apersonal nature of the desire at work here: it does not coincide at all with the individual biographies of the protagonists. On the contrary, it actively reinvents it as they rewrite each other's lives, intervening energetically into its course. There is an enormous investment of the memory and of the imagination at work in the space of the encounter between $\mathrm{V} \& \mathrm{~V}$; something which mobilizes the roots of their embodied genealogy, but transcends it: a becoming-other.

The most recurrent affect that Woolf gathers from her geometrical-geological and cosmic appreciation of Vita are images of radiance and vitality - such as the porpoise, pink light, the pearls - which occur systematically throughout her writings. Vita produces a diagram that contains forces of the utmost intensity: a quality of the light, coupled with a degree of intensity that may alternatively generate desire or trigger an outburst of comic laughter. Vita becomes a factor that introduces acceleration in the pulse of life, the opening up of possibilities, like the fluttering of wings before one takes the flight. Vita not merely re-presents but actually enacts and organizes physically as well as in writing the becoming-woman of Virginia Woolf. A becomingwoman, becoming-animal that has a distinctly marine quality about it, so ubiquitous are the images of fluidity, flowing, waves and sea animals. It does mark a fundamental moment in Woolf's race against time, the "becoming-imperceptible," which is the space where she could finally write. Hence the importance of the non-functional, apersonal space of writing as a sort of launching pad, a legal addiction that brings on a muchneeded acceleration of life, something that propels the writer onwards and forward. It is this "push" that constructs simultaneously the field of becoming and also the space for the corpus of writing. Accordingly, the assemblage of forces that activate the becoming-Orlando of Vita requires a careful phase of composition of forces that go through the becoming-woman of Virginia and the becoming-lesbian of both $\mathrm{V} \& \mathrm{~V}$, but only in order to move on, to keep on becoming until that last recognition of the bond to Vita as an imperceptible and all-encompassing life force. 


\section{intensive genre}

A pattern of de-territorialization takes place between them which runs parallel to and in and out of their respective and mutual existences, but certainly does not stop there.

It will have been a joyful and towering passion, though not entirely Virginia's or Vita's or my own or yours. You cannot have your own "plane of immanence" and still hold onto it. You can only share in the composition of one, in the company of others. One does not run with Woolf alone: women, even Virginia Woolf herself, must learn to run with other (s/he)-wolves. How much of it she could or could not take raises the issue of sustainability, but such a question can never be settled in isolation. It is a matter for negotiations, dosages and adjustments that can only take place interactively. They mark the place of the encounter. "Too much-ness" and hence the question of limits is as crucial in pleasure as it is in pain. Learning to dose and time it is the alchemy of a successful relationship, the stake of which includes the successful outcome of respective lives and life-projects, as well as the mutual fulfilment of the participants. A whole world is always implicated when a plane of immanent becoming is composed. Two is quite a crowd, when one is a multiple, complex and de-personalized entity to begin with.

The real-life Vita recognizes this interdependence, much as she had acknowledged from the start her friend's superior literary genius. After reading Orlando, for which she is the model, she actually fails to cope with the shock:

How could you hang so splendid a garment on so poor a peg? [...] Also, you have invented a new form of narcissism - I confess - I am in love with Orlando - this is a complication I had not foreseen. (Vita to Virginia, 11 October 1928 in Salvo and Leaska 305)

The life that Virginia sees in her is something that Vita herself deeply aspires to. This is nothing to do with narcissistic delight - it is actually a sort of yearning on Vita's part for the potential that lies not so much in her as in the encounter between herself and Virginia. It is simultaneously the slightly ashamed recognition of her own limitations: ("I'm not that good, really!"), and the grateful recognition of what she owes to her lover's passionate enhancement of the life that is in her ("Thank God you saw that in me!").

In other words, the relation between what in psychoanalysis is called the empirical level (the real-life Vita) and its symbolic representation (the leading character in Orlando) is no longer adequate to make sense of the intense transformation that takes place around the field of forces that is activated by $\mathrm{V} \& \mathrm{~V}$. The empirical psychology of the two women has nothing to do with this; the psychoanalytic notion of identifications is equally inadequate to account for the magnitude of the exchange that takes place between these two high-powered subjects. This becoming is not about being faithful to the authority of past experience and the solidity of foundations. It is about inventing it together in the space that is framed by the encounter between the two of them out of the transitory flows of multiple and incoherent experiences of all kinds, speeds and intensity, spaces where transformation can occur. The life that flowed between V \& V certainly was an intensified and accelerated space of becoming.

\section{an ethics of sustainability, a politics of affirmation}

Flesh is only the thermometer of becoming. The flesh is too tender. The second element is not so much bone or skeletal structure, as house or framework. The body blossoms in the house. (Deleuze and Guattari, What is Philosophy? 179)

In the framework of an ethics of joyful affirmation the dilemma is clear. One oscillates between positive and negative passions, gratification and resentment, gratitude and envy. Ultimately I find that Vita settles for the more ethical option because she transforms negative into positive passions and consents to go along with the process of alchemical transformation of her own life and image, which Virginia has actualized. Vita, too, goes running with Woolves. A transcendence of negative into positive passions is needed here, a qualitative transformation of potentially destructive emotions such as competition, jealousy and envy. Without such alchemical shift, no affect is sustainable. Potentia can 
endure only if it receives the feedback of positive and life-enhancing charges. And V \& V both want their passion to endure because it provides intensity and added meaning to their lives. It also does engender, in a non-profit manner, written work that will in turn endure.

In other words, one's affirmation of the life that one is shot through with is materially embodied and embedded in the singularity that is one's enfleshed self. But this singular entity is collectively defined, interrelational and external: it is impersonal but highly singular because it is crossed over with all sorts of "encounters" with others and with multiple cultural codes, bits and pieces of the sticky social imaginary which constitutes the subject by literally gluing it together, for a while at least. This is not an atomized individual but a moment in a chain of being that passes on, goes through the instance of individuation but does not stop there, it moves on nomadically, by multiple becomings: zoe as relentless vitality.

If instead of conceptualizing fluid identities spatially one also projects them temporally as moments of being (following Virginia Woolf), the coherence and the unity of the self appear as the result of repetition, of orchestrated returns. Virginia Woolf knows this not only intuitively but also because her own psycho-pathology opens her eyes to the fragility of Life. It also made it imperative for her to find some balance, some stability within the exhausting rollercoaster of her embodied fluctuating self. Relationships, especially her life-long love for Vita, were simultaneously stimulants and stabilizers: points of impact that could cause internal catastrophes (strong passions, unfulfilled desires, jealousy, and so on), but also points of harmony that could engender the bliss of sustainable intensity.

Moments: spatio-temporal zones, chronotropes, fleeting and contingent. They are just enough, however, to get her through the day, through to the next book, the penultimate diary entry, the last letter to Vita. Just enough, until Virginia could not take it any more and decided to walk back into her liquid element: death by water. For someone who had made fluency and fluidity into more than a style, they were her mode of relation. This partiality, this fluid

\section{braidotti}

interactivity, is the stuff coherence can be made of, if by coherence we do not mean the despotic solidity of a relationistic self or the hierarchically ordained implementation of a moral agency. Coherence is a matter for a posteriori, external, relational and momentary synchronizations. One's ability to remember it and reconstruct it as a unified block is the necessary, albeit delusional, expression of a yearning for a unity, a self-presence, which is not within the reach of the humans of today - if ever it was. Molar memory tricks us into believing that the self is a linear, self-present entity. A molecular nomadic counter-memory knows, however, that this is not the case. "It will have been me" is the mode that best expresses the impersonality and yet also, paradoxically, the deep faithfulness of the self - a self that endures, that painfully and joyfully goes on. That capacity to endure is collective, it is to be shared. It is held together by narratives, stories, exchanges, shared emotions and affects. It is neither equal to itself nor does it guarantee selfperpetuation. It is a moment in a process of becoming; as Virginia Woolf puts it: "But when we sit together, close [...] we melt into each other with phrases. We are edged with mist. We make an unsubstantial territory" (Woolf, The Waves 11).

There is something extremely familiar and almost self-evident about these processes of transformation of the self through an other who triggers processes of metamorphosis of the self. That is precisely the point. What happens is really a relocation of the function of the subject through the joining of memory and the imagination into propelling a vital force that aims at transformation.

As the case of $V \& V$ shows, however, the ethical moment is not so much the ascetic withdrawal from the world of negativity, of potestas with its quick, short-term, hit-and-run successes. It rather rests in the act of transcending the negativity itself, transforming it into something positive. This transformation is only possible if one does not sit in judgement either upon oneself or upon others, but rather recognizes within oneself the difficulties involved in not giving into the paranoid-narcissistic selfnexus. In fact, it is only at the point of utter 
destitution of one's "self" that the activity of transformation of negativity can actually be undertaken.

This effort requires endurance - some pain and some time - but it also calls for creativity, in so far as one needs to provide precisely what one does not immediately dispose of: positive passions. They have to be created in a process of patient cultivation of and efforts towards the kind of interaction with others that is likely to generate productive ethical relations. Affirmation, the result of a process of transformation of negative into positive passions, is essentially and intrinsically the expression of joy and positivity. This is constitutive of the potentia of the subject. Such potency, however, is a virtuality, which needs to be materialized in very concrete, embodied conditions of expression. Bringing about such movements or mass of affectivity is crucial to the process of becoming as actualization. The ethical moment consists in overcoming the slight sense of shame, the ethical nausea that marks the recognition of the intrinsically negative structure of one's passions. In other words, the ethical act consists in relinquishing the paranoid-narcissistic ego and installing instead an open-ended, interrelational self.

It is the empowerment of the positive side that marks the ethical moment of transformation, the reversal of the negative dialectic and its eternal repetitions, the transcendence of one's starving ego. What matters most is the process by which the transformation takes place, which is neither painless nor self-evident. Hence the importance of literature, the arts, theatre, music and film. They do not fulfil merely an illustrative function but are the privileged field of application for the kind of conceptual creativity that Deleuze would like to make operative also within philosophy. What is expressed as a result of this process is a force of affirmation, the potency of a joy that goes beyond the metaphysical divide of sexual or other forms of differentiation. And yet the affirmation of that life force requires as its unalienable and inevitable starting-point the process of becomingwoman. It requires it of $\mathrm{V} \& \mathrm{~V}$, as it does of Deleuze; indeed, of any reader.

Paradoxically, this requires also the recognition of the impersonality of the many forces that compose us. Sustaining them, so as to endure positive changes, is the key political and ethical concern of an era of transition like ours. Finding adequate representation for these processes is a challenge for all thinking beings. One that is best met not by critique but by taking the risk of creativity. A risk that may involve the kind of cognitive and affective stutter that shatters all uncertainties and opens the doors of perception to multiple lines of unexpected possibilities. Changes of this magnitude mark qualitative shifts and internal forms of mobility. They can happen any time, anywhere and whenever subjects become events, or assemblages. Then Virginia Woolf's moth flutters its wings and "Life" rushes onto you with intensive, untimely and unending vitality.

\section{post-gender? intensive genre}

Life (bios-zoe) has no brand-name on it nor does it have a price-tag attached to it. It does not flow within the constraints of a phallogocentric scheme of signification that imposes its old narrative: desire as lack; alterity and/as negativity; the burden of Being that coincides with consciousness. None of this applies any longer. Psychoanalysis cannot do justice to these kinds of concrete and highly singular processes of becoming. We are better off seeing $\mathrm{V} \& \mathrm{~V}$ as a transversal block of becoming, a plane for the realization of forces that transcend them both and yet require their presence and affinity in order to become actualized. Forces that are concentrated, focused and activated in the space between them and aim at the fulfilment of their own potentia. These forces are the accelerations of pure becoming.

Three concepts are crucial here. The first concerns the irrelevance of the category "same sex" to account for the complex and multiple affects generated in the relation between two beings. Virginia and Vita may happen to be two morphological empirical embodied subjects, and yet the space of becoming that connects them is complex, multiple and multi-layered. A polymorphous and highly sexual text such as Orlando is the perfect manifesto for it. The homophobic assumption that same-sex relationships cause 
fusion and confusion in so far as they fail to establish sufficiently strong boundaries of alterity is flatly rejected by the experience of highsingularity and intense definition which emerges from the encounter of Virginia with Vita. The fact that $\mathrm{V} \& \mathrm{~V}$ meet within this category of sexual "sameness" encourages them to look beyond the delusional aspects of the identity ("women") that they supposedly share. This proliferation of differences between women and within each one of them is evident in the outcomes and the products of their relationship, be it in the literature which V \& V produced, or in the many social, cultural and political projects they were engaged in. These included marriages, motherhood and child-rearing, political activism, socializing, campaigning, publishing and working as a publisher, gardening and the pursuit of friendships, of pleasures and of hard work.

Virginia and Vita propose an ethical model where the play of sameness-difference is not modelled on the dialectics of masculinity and femininity; rather, it is an active space of becoming, which is productive of new meanings and definitions. It is in this spirit that Irigaray praises the specific instance of feminine homosexuality as a moment of high symbolic significance in confirming a woman's sense of self-worth. This primary narcissism, this love of one-self as reflected in the eyes of another who is morphologically "the same," is, according to the early Irigaray, a necessary precondition to the affirmation of a positive difference that repairs the symbolic damage suffered by women in a phallogocentric system. This is not essentialism but rather a molecular, transversal space of formation of collectively sustained microsingularities.

In other words: sexuality de-territorializes and undoes the actual gender of the people it involves in the process of becoming. The assemblage composed by $\mathrm{V} \& \mathrm{~V}$ as blocks of becoming is post-gender but not beyond sex - it is actually deeply embedded in sexuality and can be best understood in relation to neo-vital politics. An important question that can be raised here is: what happens to gender if sexuality is not based on oppositional terms? What happens when there is sexuality without the possibility of heterosexual

\section{braidotti}

or homosexual union? (MacCormack). What happens is vitalist erotics, which includes intensive de-territorializations, unhealthy alliances, hybrid cross-fertilizations, productive anomalies and generative encounters.

The second remark is that the disappearance of firm boundaries between self and other, in the love encounter, in intense friendship, in the spiritual experience as in more everyday interpersonal connections, is the necessary premise to the enlargement of one's fields of perception and capacity to experience. In pleasure as in pain, in a secular, spiritual, erotic mode that combines at once elements from all these, the decentring and opening up of the individual ego coincides not only with communication with other fellow human beings but also with a heightening of the intensity of such communication. This shows the advantages of a non-unitary vision of the subject. A de-personalization of the self, in a gesture of everyday transcendence of the ego, is a connecting force, a binding force that links the self to larger internal and external relations. An isolated vision of the individual is a hindrance to such a process.

The third comment is that such sets of interconnections or encounters constitute a project, which requires active involvement and work. Desire is never a given. Rather, like a long shadow projected from the past, it is a forwardmoving horizon that lies ahead and towards which one moves. Between the no longer and the not yet, desire traces the possible patterns of becoming. These intersect with and mobilize sexuality, but never stop there as they construct space and time and thus design possible worlds by allowing the unfolding of ever-intensified affects. Desire sketches the conditions for the future by bringing into focus the present through the unavoidable accident of an encounter, a flush (Woolf, Flush), a sudden acceleration that marks a point of non-return. Call it falling in love, if you wish, but only if you can rescue the notion from the sentimental banality into which it has sunk in commercial culture. Moreover, if falling in love it is, it is disengaged from the human subject that is wrongly held responsible for the event. Here, love is an intensive encounter that mobilizes the sheer quality of the light and the shape of the 
landscape. Deleuze's remark on the grasshoppers flying in at 5 p.m. on the back of the evening wind also evokes non-human cosmic elements in the creation of a space of becoming. This indicates that desire designs a whole territory and thus it cannot be restricted to the mere human persona that enacts it. We need a postanthropocentric theory of both desire and love in order to do justice to the complexity of subjects of becoming.

The final point concerns the specificity of the intensive genre and its relevance as an analytical tool by which we can assess the ethical impact of texts, regardless of their formal characteristics and categorizations as either scientific/artistic/philosophical, or otherwise. As Deleuze and Guattari argue in their analysis of Woolf, it is the expressive potency of the text that counts, that is, the transversal force of an intensive genre that displaces such categories and demands instead an ethology of forces as system of indexation of what a text is capable of mobilizing and actualizing in the ways of affects, concepts and percepts.

Vita herself does justice to this process of intensive de-territorialization by accepting to become other than she is, engaging with great generosity with her own reflected image. Fulfilling the nomadic prophecy, she ends up becoming her conceptual persona: thus, she becomes a mere reader and not the main star of the process of becoming-Orlando. Being an aristocrat, and a much celebrated author in her own right, this displacement required some humility and flexibility on Vita's part - qualities in which we know that she was notoriously deficient. Yet she displays surprising skills of adaptation by letting her narcissism be gratified: "I love myself as Orlando!," but simultaneously blown to smithereens, not only in the sense of "I will never have been as fascinating and complex as Orlando" but also "Orlando is the literary creation of a woman who is a much greater writer than I will ever be!"

Thus, it is Vita's shameful recognition of her failing, not the jubilant assertion of her triumph, which opens the gates through which flows the intensity that shapes the encounter between $\mathrm{V} \& \mathrm{~V}$. The moment of negative passion (envy, resentment, feeling of dispossession) is the prelude to the ethical gesture that involves transcending the negativity and accepting the displacement of the self through the impact of an other that is so very close. This is a case of destitution of the ego, not of its triumphant apotheosis. This is also the ethical moment in their interaction, which rescued Orlando from being an act of cannibalistic consumption of the other and turns it into one of the greatest love stories of all times. Similarly, Virginia's selfeffacement is crucial to the whole process of being able to sustain, provoke, record and return the life that is in Vita, amplified to the $n$th power. Such is the task of potentia, and such is the genius of Virginia Woolf's writing.

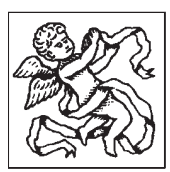

\section{note}

I The distinction potestas/potentia expresses the difference between the negative or restrictive aspects of power and the positive or affirmative ones. This distinction has become standard in neo-Spinozist democratic political theory.

\section{bibliography}

Ansell Pearson, Keith. Germinal Life: The Difference and Repetition of Deleuze. London and New York: Routledge, 1999.

Benjamin, Jessica. The Bonds of Love: Psychoanalysis, Feminism and the Problem of Domination. New York: Pantheon, 1988.

Braidotti, Rosi. Metamorphoses: Towards a Materialist Theory of Becoming. Cambridge: Polity, 2002.

Braidotti, Rosi. Patterns of Dissonance: A Study of Women in Contemporary Philosophy. Cambridge: Polity, 1991.

Braidotti, Rosi. Transpositions: On Nomadic Ethics. Cambridge: Polity, 2006.

Colebrook, Claire. "Introduction." Deleuze and Feminist Theory. Ed. lan Buchanan and Claire Colebrook. Edinburgh: Edinburgh UP, 2000. I-17.

Deleuze, Gilles and Félix Guattari. Mille plateaux. Capitalisme et schizophrénie II. Paris: Minuit, 1980. 
English translation: A Thousand Plateaus: Capitalism and Schizophrenia. Minneapolis: U of Minnesota P, 1987.

Deleuze, Gilles and Félix Guattari. Qu'est-ce que la philosophie? Paris: Minuit, 1991. English translation: What is Philosophy? New York: Columbia UP, 1992.

Eliot, George. Middlemarch. London: Penguin, 1973.

Gatens, Moira and Genevieve Lloyd. Collective Imaginings: Spinoza, Past and Present. London and New York: Routledge, 1999.

Glissant, Edouard. Poétique de la relation. Paris: Gallimard, 1990. English translation: Poetics of Relation. Ann Arbor: U of Michigan P, 1997.

Grosz, Elizabeth. "A Thousand Tiny Sexes: Feminism and Rhizomatics." Gilles Deleuze and the Theater of Philosophy. Ed. Constantin V. Boundas and Dorothea Olkowski. New York and London: Routledge, 1994. 187-210.

Guattari, Félix. Chaosmosis: An Ethico-aesthetic Paradigm. Sydney: Power, 1995.

Irigaray, Luce. "Love between Us." Who Comes after the Subject? Ed. E. Cadava, P. Connor and J.L. Nancy. New York and London: Routledge, 1991. 167-77.

Lee, Hermione. Virginia Woolf. London: Chatto, 1996.

MacCormack, Patricia. Cinesexualities. London: Ashgate, 2008.

Nicolson, N. (ed.). Vita and Harold: The Letters of Vita Sackville-West and Harold Nicholson. New York: Putnam's, 1992.

Nicolson, N. and J. Trautmann (eds.). The Letters of Virginia Woolf. Vol. III 1923-1928. New York and London: Harvest, 1977.

Probyn, Elspeth. Outside Belongings. New York and London: Routledge, 1996.

Salvo, L. de and M.A. Leaska (eds.). The Letters of Vita Sackville-West to Virginia Woolf. London: Macmillan, 1984.

Stimpson, Catharina. "The Female Sociograph:The Theater of V. Woolf's Letters." Where the Meanings Are. New York: Methuen, 1988.

Woolf, Virginia. The Diary of Virginia Woolf, Volume 3 (1925-1930). New York and London: Harvest, 1980.

Woolf, Virginia. Flush. London: Penguin, 1993.

\section{braidotti}

Woolf, Virginia. Orlando. London: Grafton, 1977.

Woolf, Virginia. The Waves. London: Grafton, 1977. 